\title{
Trend Study of Educational Technology in Physical Education of Colleges and Universities
}

\author{
Yuan Zhao \\ Jiangxi Normal University \\ Nanchang, China \\ 464235233@qq.com
}

\author{
Kaiqiang Guo \\ Jiangxi Normal University \\ guokaiqiang2008@yeah.net
}

\begin{abstract}
By analyzing the current situation of domestic educational technology application in colleges and universities' physical education, the assay is going to identify important achievements, analyze existing problems, and elaborate the development trends of physical education in colleges and universities. In this thesis, we considered that the inevitable new trends of physical education in colleges and universities was an innovation of teaching ideas, modes and methods, which reflects in the reform of teaching methods and the innovation of training means.
\end{abstract}

Keywords-educational technology; colleges and universities; physical education; trends

\section{INTRODUCTION}

After years of development, modern education technology in physical education discipline has achieved outstanding achievements that unprecedented attention was given by sports teachers and researchers, and an agreement was reached that full use of educational technology can not only benefit the design, development, utility, assessment and management of sports teaching training process and teaching training material, which help colleges form self characteristics, but also help in solving the bottleneck problems in physical education and thus achieves the optimization of the combination of theory and practice in the physical education process of colleges and universities.

\section{Related ORganizations INVOLVED IN THE}

DEVELOPMENT Of EdUCATIONAL TECHNOLOGY IN PHYSICAL EDUCATION OF COLLEGES AND UNIVERSITIES

\section{A. Professional Committee of China Association for Technology in College Sports Teaching}

It is one of the largest academic community of China Association For Educational Technology. Referred to as Physical Education Committee, it is founded in November of 1987 in Jinan University in Guangzhou. It now has over 80 governing units and mainly devotes in the research and application of education technology, network courses, CAI courses, multimedia teaching and teaching reforms, which has largely broadened the application of modern educational technology in sports teaching in colleges and universities.

\section{B. Sports Computer Use Branch of China Sport Science Society}

It found five study groups: computer-assisted exercise training group, educational technology group (colleges Group), educational technology group (PE group), physical education management group and electronic athletics study group. The five study groups are of outstanding features and focus on five different research directions, which strive for better academic, application and demonstration of educational technology in physical education of colleges and universities and make a great contribution to all-round and concerted development in China's sports.

\section{THE SOCIAL IMPACT OF RESEARCH RESULTS}

With the application of educational technology in physical education, the educational technology has become a breakthrough tool for the development of teaching methods. Moreover, the combination, mutual penetration and mutual promotion of modern education technology theory and physical education practice has become the driving force for physical education advance and promote sports teaching from experience to the information age rapidly in all of aspects. Nowadays, the modern educational technology, the application of computer in physical education of colleges and universities, sports training, competition and management are playing an indispensable role.

In the three major national educational technology application competitions from 2009 to 2014, the physical education major has achieved an outstanding results (see Figure I.). 


\begin{tabular}{|c|c|c|c|c|c|c|c|}
\hline Competition & Organizers & Rank & $\begin{array}{l}2 \\
0 \\
0 \\
9\end{array}$ & $\begin{array}{l}2 \\
0 \\
1 \\
0\end{array}$ & $\begin{array}{l}2 \\
0 \\
1 \\
2\end{array}$ & $\begin{array}{l}2 \\
0 \\
1 \\
3\end{array}$ & $\begin{array}{l}2 \\
0 \\
1 \\
4\end{array}$ \\
\hline \multirow{3}{*}{$\begin{array}{l}\text { The } \\
\text { Multimedia } \\
\text { Courseware } \\
\text { Grand Prix }\end{array}$} & \multirow{3}{*}{$\begin{array}{lr}\text { The Information } \\
\text { Center of The } \\
\text { Ministry } \\
\text { Education }\end{array}$} & $1 \mathrm{st}$ & 1 & 2 & 4 & 1 & 3 \\
\hline & & 2nd & 1 & 2 & 2 & 1 & 0 \\
\hline & & 3rd & 1 & 3 & 1 & 2 & 0 \\
\hline \multirow{3}{*}{$\begin{array}{l}\text { The National } \\
\text { Education } \\
\text { Information- } \\
\text { Based } \\
\text { Teaching } \\
\text { Grand Prix }\end{array}$} & \multirow{3}{*}{$\begin{array}{l}\text { The Ministry of } \\
\text { Education, The } \\
\text { Central Audio } \\
\text { Visual Hall }\end{array}$} & $1 \mathrm{st}$ & 0 & 0 & 0 & 0 & 0 \\
\hline & & 2nd & 0 & 1 & 0 & 0 & 0 \\
\hline & & 3rd & 0 & 0 & 1 & 0 & 4 \\
\hline \multirow{3}{*}{$\begin{array}{l}\text { National } \\
\text { University of } \\
\text { Computer } \\
\text { Courseware } \\
\text { Evaluation } \\
\text { Conference }\end{array}$} & \multirow{3}{*}{$\begin{array}{ll}\text { The Ministry of } \\
\text { Education } \\
\text { Computer of } \\
\text { Higher Education } \\
\text { Steering } \\
\text { Committee }\end{array}$} & $1 \mathrm{st}$ & 0 & 0 & 0 & 0 & 0 \\
\hline & & 2nd & 0 & 0 & 0 & 0 & 0 \\
\hline & & 3rd & 0 & 0 & 0 & 0 & 1 \\
\hline
\end{tabular}

FIGURE I. THE NATIONAL AWARDS OBTAINED BY PHYSICAL EDUCATION COURSEWARE OF COLLEGES AND UNIVERSITIES IN 2009-2014

\section{A. Project Features}

The projects are including table tennis, badminton, tennis, tai chi, aerobics, cheer leading, sports dancing, public sports course basketball, volleyball, track and field. All these courses are students' favorite in college.

\section{B. Educational Technology Type Features}

The online courses and video-sharing accounts for the main content of educational technology, which are in accordance with the provisions and requirements of Modern Technical Standard System of Distance Education And The 11 Trial Version of V1.0 Standard of ministry of education.

\section{Figure I. Analysis}

We can see from the Figure1., the rank and the number of awards are increasing year by year, besides, in the The National Education Information-Based Teaching Grand Prix hold by The Ministry of Education, The Central Audio Visual Hall and National University of Computer Courseware Evaluation Conference hold by The Ministry of Education of Computer In Higher Education Steering Committee, sports education have both got a breakthrough achievement, which was really not a easy thing.

\section{THE PROBLEMS OF EDUCATIONAL TECHNOLOGY IN PHYSICAL EDUCATION OF COLLEGES AND UNIVERSITIES}

\section{A. Excluded From the Independent Class 2 Research Direction Directory}

The education technology in physical education has not been classified as an independent class 2 research direction directory, which hinders the development of the systematic layout and integrity of the system, leading to the overall advantages of technology education can not be achieved and the incomplete development of education technology in physical education of colleges and universities.

\section{B. Unable to Form a Unified Team}

The education technology research efforts have not been integrated to be a unified team. Nowadays, the backbone strength of educational technology are mainly majored in computer, education or communication who do not have a great knowledge of sports. The lack of the combination of education technology theory and sports skill practice; and the ignorance of construction of sports specialty but focusing on the theory design, making the unable to achieve the breakthrough in the theoretical disciplines.

\section{Inadequate Funding and Uneven Development of Educational Technology}

The inadequate funding and uneven development of educational technology in different schools restricts the comprehensive application of educational technology. The investment funds needed in the application of educational technology is very big, especially in the construction of education information teaching environment. Nowadays, the application of educational technology in physical education of colleges and universities are not satisfied, which mainly reflects in the insufficience of boutique resource sharing courses and boutique resource public video classes and so on. Take Jiangxi province as an example, in 2011 to 2014, the provincial project courses are only 5 , which is far behind all other subjects.

Incompletely Change of the Concept of Physical Education Teachers

The physical education teachers have not completely changed their concept of professional experience teaching, which inveterately limits the scope of research and the practice in educational technology. Over the years, the sports professional skills course is based on "physical activity", which is a core course in college physical education. In fact, of all the practical courses in physical education, most of the courses are skill-oriented projects. However, teachers occupies the leading place in the teaching process by limb demonstration and evaluation, ignoring the dominant role of students, thus leading to the situation that more active the teacher be, the more passive the students be. Practice has proved that the teaching goals can not be achieved and existing problems can not be solved effectively by traditional skills practice or solely the teacher's explanation, demonstration, evaluation of physical knowledge.

\section{Insufficient Development of Physical Education Software and Simplicity of the Design of Teaching Environment}

The development of physical education software is insufficient, and the design of teaching environment is too simple. The main shortage level are as follows:

- The development of physical education software are basically focused on public fitness project. The scope of projects are not enough and the professionalism is not strong.

- The design of teaching environment is too simple, which reflects in the digital cinema presentation, imitation of course design and so on. Though the ornamental stuff are attractive to the students, the interaction between the teachers and students are 
becoming less and the participation of students are missed. How to improve the students' proficiency level and innovate the teaching methods are becoming imminent problems in physical education.

- The lack of network interactive teaching and use of multimedia network, the teachers and students can not get more effective communication after class, which can not show effectively extension of educational technology in physical education.

- The guidance tool of modern educational technology enables students to have access to excellent software, which benefits the coaching and personalized learning. The teachers can monitor the development of students and give them timely guidance whenever needed.

\section{NEW TRENDS OF PHYSICAL EDUCATION IN COLLEGES AND UNIVERSITIES}

The key points and difficult points of educational technology in colleges and universities are the case studies of the design, development and application of learning environment theory. The learning environment theory emphasizes on the learning initiative, collaboration and situational analysis, which means improving the construction of knowledge and the promoting the transfer of learning.

\section{A. Changes in the Way Students Learn}

The students changed from passively accept and repeatedly skills practice to active learning skills; they use a variety of professional information resources to recreate their own learning skills and thus master their ability of how to learn. In this case, students cultivate their own independent thinking abilities, appearance thinking abilities and problems-solving abilities while training their motor skills.

\section{B. Changes of Teachers' Role}

The teachers changed from the traditional interpreter and demonstrator to an instructor and a helper. The teachers are no longer solely guide to practical skills, but an instructor who helps the students to be a self learner. At the same time, the teachers can not only use the CAI courseware to guide students to understand the professional skills of movement structure features and application methods, but also deal with the instruction of professional sports skills during the action and correct the error methods. The professional sports skills and abilities of the teachers are basic for the curriculum integration. The PE teachers should have the abilities to make full use of information equipment and information resources, as well as the abilities to process information, create new information and do researches.

\section{Changes in the Role of the Media}

The teaching media changes from the tool for the PE teachers to demonstrate to the tool for the students to learn knowledge and construct their own knowledge system. At the same time, the teaching media is not only the network, but also the learning objects of students.

\section{Progresses in Education Resources Expansion and Teaching Software Design}

Firstly, the expansion and innovation of education resources in colleges and universities can improve students' cooperative learning, which benefits the development of students' cognitive abilities and the cultivation of students' explore consciousness, skill practice abilities etc. Secondly, the approaches of education software development are becoming more micro, diversified and personalized. The innovation of instructional design platform is the key factor to improve teaching results and the main tool for minimizing the differences between the instructional design theories and the teaching practice. It is also useful means to solve the bottleneck problems in the effectiveness of teaching and learning, which may give a strong impact on traditional teaching and assessment.

\section{E. Continuous Innovation of Educational Technology Continuously Reforms the Learning Environment}

The continuous innovation of educational technology continuously reforms the learning environment, especially in computer image, graphics technology in sports training and teaching, which has taken an irreplaceable role in physical education. The continuous innovation of educational technology can fully solve the difficult problems and the bottleneck problems in sports training and sports teaching, and the auxiliary system of it can greatly teaching effects and athletic performance, which including the following points:

- Establish the comparison system of teaching evaluation and feedback.

- Improve the quality of technical movements, effectively solve the key problems and difficulty problems.

- Analyze the characteristics of technical movements, give scientific guidance in teaching and training.

\section{CONCLUSIONS}

The application of educational technology in physical education of colleges and universities has been seen as a reform and innovation of teaching and training methods. Besides, the application of modern educational technology in physical education practice has achieved the transformation of teachers' role and thus improve the educational technology and abilities of teachers. Moreover, the curriculum construction should appropriately combine the application of educational technology with the teaching ideas, goals, methods and means of traditional physical education curriculum, thus to achieve the innovation of teaching ideas, modes and methods, which also reflects an inevitable trend of educational technology in physical education of colleges and universities.

\section{ACKNOWLEDGMENT}

Found Project; Responsible Person Kaiqiang Guo, Supported by Boutique of Quality Resource Sharing Program. Document No. [2014]38 Issued by the Education Department of Jiangxi Province. 


\section{REFERENCES}

[1] Kaiqiang Guo, CAI Teaching Design and Development for referee scoring of table tennis-a case of Tennis Excellent Courses of Jiangxi Normal University. IEEE Catalog Number: CFP1153K-PRT, ISBN 9781-6128-4774-0.

[2] Kaiqiang Guo, College sports professional teachers technical exquisite course network teaching design is discussed. [J]. Melbourne-Australia, 2010 (12).

[3] Kaiqiang Guo, Research on college tennis intensive courses online teaching design Taking Jiangxi Normal University as an example. [J]. Creative Education (ISSN: 2151-4771) P52-56.

[4] Wsong Bu, Kaiqiang Guo, Design and manufacture of tennis teaching software in excellent courses. [C]2013 Proceedings of National Sports Computer Paper Session.

[5] M. Young, The Technical Writer's Handbook. Mill Valley, CA: University Science, 1989.

[6] http://csteic.org/

[7] http://www.csss.cn/cn/xuezu.html?i=12

[8] http://www.etsport.org/

[9] http://www.mtsa1998.com.cn/

[10] http://www.uken.cn/ 